\title{
Novel chitinolytic bacteria from the shrimp shell processing waste
}

\author{
MASHURI MASRI ${ }^{1, \boldsymbol{v}}$, EKA SUKMAWATY $^{1}$, LASINRANG ADITIA ${ }^{1,2}$ \\ ${ }^{1}$ Department of Biology, Faculty of Science and Technology, UIN Alauddin. Jl. H.M. Yasin Limpo No. 36, Romangpolong, Gowa 92118, South \\ Sulawesi, Indonesia. Tel./fax.: +62-411-8221400, •email: mashuri.masri@uin-alauddin.ac.id \\ ${ }^{2}$ Graduate Program of Biology, Department of Biology, Faculty of Science and Technology, UIN Alauddin. Jl. H.M. Yasin Limpo No. 36 , \\ Romangpolong, Gowa 92118, South Sulawesi, Indonesia
}

Manuscript received: 19 February 2021. Revision accepted: 19 April 2021.

\begin{abstract}
Masri M, Sukmawaty E, Aditia L. 2021. Novel chitinolytic bacteria from the shrimp shell processing waste. Biodiversitas 22: 2672-2681. Chitinase is an enzyme that hydrolyzes chitin ( $\beta-1,4$ Nsetyl-D-glucosamine polymer). Several types of microorganisms produce chitinase that contributes to basic science and application. The role of chitinase enzyme is widely utilized in various fields, such as health as an anti-tumor agent and agriculture as biological control agents in plant disease caused by fungus. The purpose of this study was to isolate novel chitinolytic bacteria from shrimp shell waste in Makassar, Indonesia, using the scatter plate method on chitin agar selective media incubated at $37^{\circ} \mathrm{C}$ for 3 days. The clear zone formation around the colony was marked as an indicator of chitinase activity performed by the certain isolate. Selection was carried out by recycling all isolates on chitin agar media, which were incubated at $37^{\circ} \mathrm{C}$ for 3 days and measured the chitinolytic index. Two of ten isolates produced the highest chitinolytic index, namely, KLA-2 (45) and KLA-4 (15) isolates. The molecular identification results showed that the KLA-2 and KLA-4 isolates were Lysinibacillus fusiformis strain WH22 and Brevibacillus reuszeri strain CMB-15, respectively. Therefore, novel chitinolytic bacteria that can produce chitinase enzyme from shrimp shell waste are L. fusiformis and B. reuszeri.
\end{abstract}

Keywords: Brevibacillus reuszeri, chitinase enzyme, Lysinibacillus fusiformis, shrimp shell waste of factory

\section{INTRODUCTION}

Chitin is a polysaccharide composed of $\beta-1,4-\mathrm{N}$ acetylglucosamine (Halder et al. 2013; Junianto et al. 2013). Chitin has a crystallized, stable, rigid, and waterinsoluble structure in the animal exoskeletons due to $\mathrm{N}$ acetylglucosamine polymer chain that contains hydrogen bonds between molecules to form microfibrils (Elieh-AliKomi and Hamblin 2016; Dliyauddin et al. 2020).

The abundance of chitin in nature is ranked in second place after cellulose and is widely distributed in the biosphere, such as the crustaceans skin (crab, shrimp, and lobster), jellyfish, insect exoskeleton structural component, fungus cell-wall (22-40\%), algae, nematodes, animals, plants, and microorganisms that contribute to the chitin availability in soil (Yurnaliza et al. 2012; Asif et al. 2020). The source of chitin can also be obtained from shrimp processing waste which consists of head and shell (Benhabiles et al. 2012; Ghorbel-Bellaaj et al. 2012). Both wastes contain high chitin levels, which are thought as a habitat for chitinase-producing bacteria (Benhabiles et al. 2012; Das et al. 2016; Ghorbel-Bellaaj et al. 2012).

Chitin can be degraded in two ways; the first is degradation by chitinolytic mechanisms which hydrolyze $\beta$-1,4-glycoside bonds and the second is chitin deacetylation, which can be hydrolyzed by chitosanase (Yurnaliza et al. 2012).

Exochitinase, endochitinase, chitosanase, and chitin deacetylase are chitinase enzymes (Yan and Fong 2015). Chitinase enzyme is produced by various organisms, including bacteria, yeasts, fungi, insects, plants, vertebrates, etc. (Das et al. 2016). Chitinase enzyme is included in the hydrolase enzyme group that can degrade chitin directly into small molecular weight material produced by microorganisms (Yan and Fong 2015), both intracellularly (Li et al. 2016) and extracellularly (Kim et al. 2017).

Chitinase enzyme has excellent potential for various field applications (Das et al. 2016). The chitin hydrolysis products, namely chitooligosaccharide compounds (chitohexose and chitoheptose) are beneficial in health as anti-tumor agents (Soeka and Sulistiani 2012). Chitooligosaccharide compounds can also increase immunity and is very helpful for AIDS, cancer, heart, and blood disease treatments applied in food, medicine, and cosmetic products (Haliza 2016). In agriculture, chitinase produced by microorganisms acts as a biocontrol for plant diseases caused by fungi ( Parnell et al. 2016; Berini et al. 2018). Chitinase causes fungus cell wall lysis that commonly contains chitin (Veliz et al. 2017; Asif et al. 2020).

Chitinase is also a very promising material in biotechnology as safe and environmentally friendly biopesticide that can degrade chitin, as a structural component of insect exoskeletons, nematodes, and fungal cell walls (Berini et al. 2018; Gupta et al. 2019; Le and Yang 2019; R. Singh et al. 2020). Chitinase also plays an environmental role as a bioconversion agent of chitin waste into single-cell proteins (Suryadi et al. 2016). Brevibacillus reuszeri and Lysinibacillus fusiformis are two groups of chitinolytic bacteria. Gurkok (2016) collected thirteen isolates of chitinolytic bacteria in the marine and terrestrial 
environments from Western Anatolia Region in Turkey (Gürkök and Görmez 2016). Meanwhile, this study collected samples from shrimp processing factory waste which had different physical characteristics.

Prospective chitinase enzyme role in people's lives encourages scientists to explore chitinolytic microorganisms, including this study which was proposed for isolating the novel chitinolytic bacteria from shrimp processing factory waste that can be used as a source of chitinolytic bacteria with many benefits in various fields. Moreover, this study also expects to reduce the waste used, which is likely to have a negative impact on the environment.

\section{MATERIALS AND METHODS}

\section{Isolation of chitinolytic bacteria}

The samples, namely skin, head, and tail, were obtained from the shrimp processing factory waste in Makassar Industrial Area (KIMA), Indonesia. Samples were weighed $100 \mathrm{~g}$ and moved to an Erlenmeyer flask containing 400 $\mathrm{mL}$ lactose broth (LB) as a fermentation medium. The fermentation medium was kept closed and stored at $4{ }^{\circ} \mathrm{C}$ (Jeyanthi Rebecca et al. 2013). This fermented liquid was used as chitinase enzyme-producing bacteria isolation process from shrimp processing waste.

\section{Colloidal chitin preparation}

Chitin from shrimp shells obtained from PT. Biotech Surindo, Cirebon, Indonesia was weighed $20 \mathrm{~g}$ and added with $400 \mathrm{~mL}$ concentrated $\mathrm{HCl}$. This mixture was then stirred for 2 hours and incubated in the refrigerator for 24 hours. The solution was filtered with glass wool, and the filtrate was added with $200 \mathrm{~mL}$ cold-distilled water and neutralized with $10 \mathrm{~N} \mathrm{NaOH}( \pm 250 \mathrm{~mL})$ at $\mathrm{pH}$ of 7 . The solution was centrifuged at $8,000 \mathrm{rpm}$ for 20 minutes at $4^{\circ} \mathrm{C}$. The supernatant was removed, and the pellet was taken and added with distilled water. This mixture was then stirred to dissolve the remaining salt and re-centrifuged at a speed of $8,000 \mathrm{rpm}$ for 20 minutes at $4^{\circ} \mathrm{C}$. The colloidal chitin pellet produced was stored in the refrigerator (Widhyastuti 2007).

\section{Isolation and selection of chitinolytic bacteria}

Isolation and selection medium used a chitin agar $(1 \%$ colloidal chitin, $0.1 \%$ peptone, $0.1 \%$ yeast extract, $0.1 \%$ $\mathrm{KH}_{2} \mathrm{PO}_{4}, 0.05 \% \mathrm{MgSO}_{4} .7 \mathrm{H}_{2} \mathrm{O}$, and $2 \%$ agar) in $100 \mathrm{~mL}$ distilled water. The solution was then homogenized with a magnetic stirrer and heated until being dissolved at a $\mathrm{pH}$ of 7. The solution was sterilized for 15 minutes at $121^{\circ} \mathrm{C}$. Isolation was carried out using the spread-plate method. In the sample (fermented shrimp processing liquid waste), dilution was serially carried out in up to $10^{-6}$. All dilutions were spread on chitin agar media and incubated at $37^{\circ} \mathrm{C}$ for 3 x 24 hours (Jeyanthi Rebecca et al. 2013; Saima et al. 2013).

The qualitative test results of chitinolytic isolate were characterized by a halo area (clear zone) around the colony. The isolates obtained were grown simultaneously by being recycled on chitin media by using a straight loop. Selection was carried out by measuring the chitinolytic index of each isolate (Kaur et al. 2012; Veliz et al. 2017). The chitinolytic index is the ratio of clear zone diameter and bacterial colony diameter as presented in the following formula: CHITINOLITIC INDEX $=\frac{\text { BHALO ZONE DIANETER }}{\text { 9DACTEIAT COIOYY }}$ (Kaur et al. 2012; Soeka and Sulistiani 2012)

All chitinolytic isolates with the highest chitinolytic index value were purified and re-cultured by inoculating the isolates onto the chitin agar and nutrient agar (NA) slant as stock for further treatment and stored in the refrigerator at $4^{\circ} \mathrm{C}$ (Soeka and Sulistiani 2012).

\section{Colony macroscopic and microscopic observations of bacterial cells}

The observation of bacterial isolates was carried out according to Bergey et al. (1984) using microscope (Olympus CX43). All isolates of chitinase enzymeproducing bacteria were observed based on the colony macroscopic characteristics (size, shape, color, elevation, edges, and surface) and cell microscopic characteristics (cell shape, Gram properties, and endospore availability).

\section{Molecular identification of chitinolytic bacteria isolates}

Molecular identification was only carried out on two bacterial isolates with the highest chitinolytic index. These bacterial isolates were determined using a 16S-rRNA sequence. The molecular identification and analysis of $16 \mathrm{~S}-$ rRNA gene were carried out through (Saima et al. 2013).

\section{DNA extraction}

DNA extraction in prokaryotic organisms is carried out through sample preparation, cell lysis, DNA binding, washing, and elution. The DNA extraction steps were based on Geneaid Presto ${ }^{\mathrm{TM}}$ Mini gDNA Bacteria Kit.

\section{Sample preparation}

One ose of bacterial samples were inserted into a sterile $1.5 \mathrm{~mL}$ microcentrifuge tube containing $200 \mu \mathrm{L}$ Gram (+) buffer added with lysozyme. This solution was homogenized by pipetting and incubated at $37^{\circ} \mathrm{C}$ for 30 minutes. The tube was vortexed after incubation and added with $20 \mu \mathrm{L}$ Proteinase K and $200 \mu \mathrm{L}$ Gram (-) buffer, then vortexed and re-incubated at $60^{\circ} \mathrm{C}$ for 10 minutes. Every 3 minutes, the tube was changed its position in the incubator.

\section{Cell lysis}

The $200 \mu \mathrm{L}$ GB Buffer (Geneaid) was added to the solution, then vortexed and re-incubated at $50^{\circ} \mathrm{C}$ for 10 minutes. The tube that contained this solution was changed its position every 3 minutes.

\section{DNA binding}

The $200 \mu \mathrm{L} \mathrm{96 \%} \mathrm{ethanol} \mathrm{was} \mathrm{added} \mathrm{to} \mathrm{the} \mathrm{solution,} \mathrm{and}$ the solution was vortexed for 10 seconds. The mixture solution was transferred into a GD column (spin column) in $2 \mathrm{~mL}$ collection tube and centrifuged at 13,100 rpm for 2 minutes. Collection tube under the spin column was then removed and replaced with new collection tube. 


\section{Washing}

The $400 \mu \mathrm{L}$ W1 buffer (Geneaid) was added to the mixture solution and the mixture solution was centrifuged at $13,100 \mathrm{rpm}$ for 30 seconds, then the supernatant in the collection tube was discarded. The $600 \mu \mathrm{L}$ wash buffer was added to the mixture solution and the mixture solution was re-centrifuged, then the supernatant in the collection tube was discarded and re-centrifuged for 3 minutes. The collection tube was discarded and replaced with sterile microcentrifuge tube at the bottom of the spin column.

\section{Elution}

The $100 \mu \mathrm{L}$ Elution buffer (Geneaid) was added into the mixture solution and stood for 3 minutes, then the mixture solution was centrifuged at the same speed for 1 minute. The DNA containing supernatant was stored in the microcentrifuge at $4^{\circ} \mathrm{C}$ as PCR template.

\section{PCR (Polymerase Chain Reaction) amplification}

PCR is an enzymatic synthesis process to multiply a specific nucleotide sequence in vitro (in the tube). The process included three stages; denaturation, annealing, and extension. This procedure was performed on isolated DNA samples. PCR mix was inserted into PCR tube. 2x KAPA2G Fast Ready Mix contained Taq DNA Polymerase, PCR buffer, $\mathrm{MgCl}_{2}$, dNTP, and $\mathrm{ddH}_{2} \mathrm{O}$. The total volume of PCR Mix was $55 \mu \mathrm{L}$ for each sample, which was then entered into the PCR machine. Amplification was performed using a PCR (Geneaid DN1100). For PCR amplification, the initial stage of pre-denaturation was at $95^{\circ} \mathrm{C}$ for 3 minutes, then denaturation was at $95^{\circ} \mathrm{C}$ for 10 seconds, annealing was at $55^{\circ} \mathrm{C}$ for 10 seconds, extension was at $72^{\circ} \mathrm{C}$ for 15 seconds in 35 cycles followed by a final extension at $72^{\circ} \mathrm{C}$ for 1 minute, which was then held at $4^{\circ} \mathrm{C}$.

\section{Electrophoresis}

$2 \%$ agarose was prepared by dissolving $2 \mathrm{~g}$ agarose in $100 \mathrm{~mL} 10 \mathrm{X}$ Tris borate EDTA and boiling until the agarose dissolved. $1 \mu \mathrm{L}$ ethidium bromide $(0.2 \mu \mathrm{g} / \mathrm{mL})$ was added and placed in a gel mold fitted with a comb. After the agarose became solid at about 30 minutes, the agarose was moved into an electrophoresis tank containing a $0.5 \%$ TBE solution. The amplified DNA sample at $5 \mu \mathrm{L}$ has then entered the tank to identify the PCR amplification product size. A 100 bp marker was inserted in the first well and followed by the amplified DNA sample. The electrodes were connected to the power supply and the electrodes were turned on for 40 minutes at 100 volts. The electrophoresis device was turned off then the gel from the device was taken. The gel was transferred to the UVtransilluminator (Geneaid DN1100) and the results were observed in a computer.

\section{Sequencing}

PCR samples contained 63F forward primer (5'CAGGCCTAACACATGCAAGTC-3') and 1387R reverse primer (5'-GGGCGGTGTGTACAAGGC-3'). These samples were sent to PT. Genetics Science, Indonesia and to $1^{\text {st }}$ BASE INT sequencing, Malaysia for base-pair mapping the base pairs. After that, these nucleotides were notified online in BLAST (Basic Local Alignment Search Tool) program in NCBI (National Center for Biotechnology Information) database. Sequences were aligned using the Clustal W program. Furthermore, phylogenetic tree construction was carried out using the neighbor-joining method with the MEGA 6 program.

\section{RESULTS AND DISCUSSION}

Samples containing skin, head, and tail were taken from the shrimp shell processing factory waste in Makassar Industrial Area (KIMA), Indonesia. In this factory, skin, head, and tail of shrimp were thrown away. Chitinase in crustaceans has a function in the degradation of old cuticle (Taira et al. 2002).

\section{Chitinolytic bacteria}

The isolation and selection results of chitinolytic bacteria from shrimp processing waste obtained ten chitinolytic bacterial isolates as shown in Table 2 .

This study found ten potential chitinolytic bacteria. Based on the data presented (Table 2), there was no correlation between Halo Zone Diameter, Bacterial Colony, and Chitinolytic Index. Furthermore, the highest chitinolytic index was found in KLA-2 (45) and KLA-4 (15). The KLA-2 and KLA-4 isolates were selected as potential chitinolytic bacteria. The chitinase activity of the two isolates can be seen in Figure 1.

Table 1. Composition of PCR mix

\begin{tabular}{ll}
\hline Reaction & $(\boldsymbol{\mu L})$ \\
\hline Nuclease Free Water & 20 \\
2x KAPA2G Fast Ready Mix & 25 \\
63F (Forward primer) & 2.5 \\
1387R (Reverse primer) & 2.5 \\
DNA template & 5 \\
Total PCR mix & 55 \\
\hline
\end{tabular}

Table 2. Halo zone diameter, bacterial colony, and chitinolytic index from several chitinolytic bacteria

\begin{tabular}{lccc}
\hline $\begin{array}{l}\text { Isolate } \\
\text { Code }\end{array}$ & $\begin{array}{c}\text { Halo zone } \\
\text { diameter }(\mathbf{m m})\end{array}$ & $\begin{array}{c}\text { Bacterial colony } \\
\text { diameter }(\mathbf{m m})\end{array}$ & $\begin{array}{c}\text { Chitinolytic } \\
\text { index }\end{array}$ \\
\hline KLA-1 & 12 & 8 & 1.5 \\
KLA-2 & 45 & 10 & 4.5 \\
KLA-3 & 15 & 8 & 1.9 \\
KLA-4 & 75 & 5 & 15 \\
KLA-5 & 13 & 5 & 2.6 \\
KLA-7 & 7 & 5 & 1.4 \\
KLA-8 & 15 & 13 & 1.2 \\
KLA-9 & 11 & 5 & 2.2 \\
KLA-10 & 26 & 7 & 3.7 \\
KLA-14 & 9 & 7 & 1.3 \\
\hline
\end{tabular}




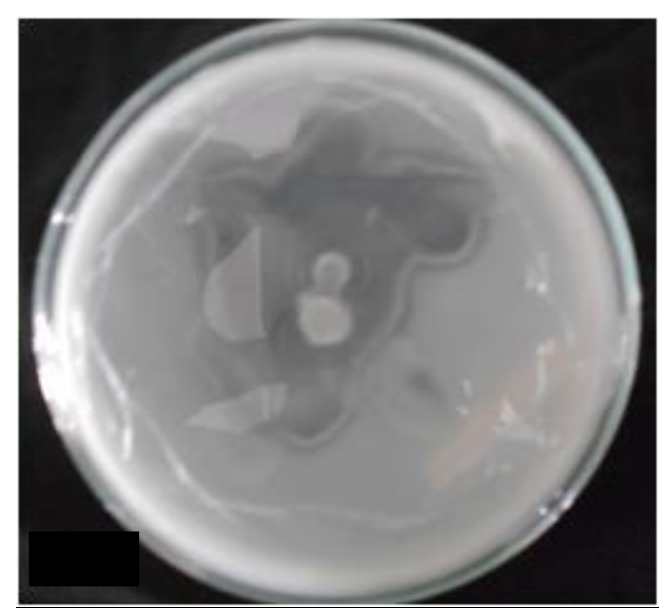

A

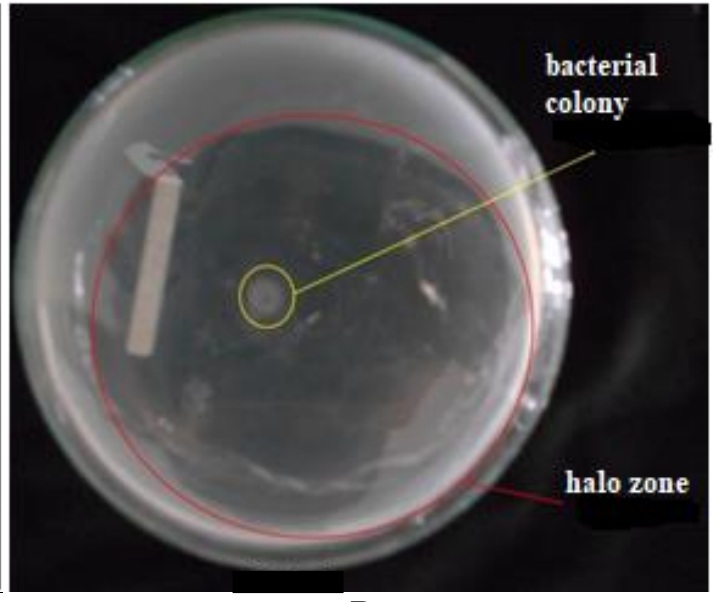

B

Figure 1. Chitinolytic activity of A. KLA-2 and B. KLA-4 isolates that formed clear zones around the bacterial colonies

The halo zone in Figure 1 represents the transparent color in the media due to the chitinase enzyme released into the media as a colorless metabolite, resulting in a clear zone formation around the bacterial colony (Noreen et al. 2018). Chitinase is an extracellular enzyme produced by chitinolytic bacteria which plays an essential role in hydrolyzing chitin (Asif et al. 2020). Extracellular enzymes are produced in cells and released into the growth medium (Z. Zhao et al. 2020).

From ten isolates, each colony with clear zone diameter was measured its colony diameter using a ruler on the third day of incubation. The measurement results obtained can be seen in Table 2. The clear zone size depends on the various bacteria's abilities to produce chitinase. The difference in chitin degradation rate can be indicated by the clear area's appearance around the colony on agar containing chitin (Yavari-Bafghi et al. 2019). These differences may be due to small differences in the encoded genes, as only the chil8D gene on Cellvibrio japonicus bacteria had fundamental roles in chitin degradation substrate (Monge et al. 2018).
This study used chitin agar as a selective medium to isolate and select chitinolytic bacteria, which contains colloidal chitin. Colloidal chitin is chitin dissolved in concentrated hydrochloric acid. Chitin agar is also a selective medium to obtain actinomycetes from water and soil (Hsu and Lockwood 1975), while colloidal chitin is chitin polymer degradation that contains chitin oligomer (Tran et al. 2019). Substrates that can be used for screening in chitin media to induce chitinolytic enzyme groups are exochitinase and endochitinase (Drewnowska et al. 2020). Screening method using chitin media was chosen due to quite practical, as capable of screening large amounts of chitinolytic isolates quickly, which can be presented either qualitatively or semi-quantitatively (Shamshina 2019).

\section{Colony macroscopic and microscopic observations of bacterial cells}

Macroscopic observations were directly carried out, while cell microscopic observations were carried out with Gram staining as a differential stain and endospore staining as a particular stain.

Table 3. Macroscopic observation of chitinolytic bacterial isolate

\begin{tabular}{|c|c|c|c|c|c|c|}
\hline \multicolumn{7}{|c|}{ Colony macroscopic } \\
\hline Isolate code & Size & Shape & Color & Elevation & Edge & Surface \\
\hline KLA-1 & Moderate & Irregular & Milky white & Flat & Rhizoid & Smooth-shiny \\
\hline KLA-2 & Moderate & Irregular & Milky white & Flat & Rhizoid & Smooth-shiny \\
\hline KLA-3 & Moderate & Irregular & Milky white & Flat & Entire & Rough \\
\hline KLA-4 & Moderate & Circular & Milky white & Flat & Entire & Smooth-shiny \\
\hline KLA-5 & Moderate & Circular & Milky white & Flat & Entire & Smooth-shiny \\
\hline KLA-7 & Moderate & Irregular & Milky white & Flat & Entire & Smooth-shiny \\
\hline KLA-8 & Large & Filamentous & Milky white & Flat & Rhizoid & Rough \\
\hline KLA-9 & Moderate & Circular & Milky white & Flat & Entire & Smooth-shiny \\
\hline KLA-10 & Moderate & Circular & Milky white & Flat & Entire & Smooth-shiny \\
\hline KLA-14 & Moderate & Filamentous & Milky white & Flat & Rhizoid & Rough \\
\hline
\end{tabular}


Table 4. Microscopic observation of chitinolytic bacterial isolates

\begin{tabular}{llcc}
\hline \multicolumn{4}{c}{ Microscopic cell } \\
\hline Isolate code & Cell shape & Gram & Endospore \\
\hline KLA-1 & Bacillus & + & + \\
KLA-2 & Bacillus & + & + \\
KLA-3 & Coccus & - & - \\
KLA-4 & Bacillus & + & + \\
KLA-5 & Bacillus & + & + \\
KLA-7 & Bacillus & + & + \\
KLA-8 & Bacillus & - & - \\
KLA-9 & Bacillus & + & + \\
KLA-10 & Coccus & - & - \\
KLA-14 & Coccus & - & - \\
\hline
\end{tabular}

Colonies that grew on agar plates were observed based on the size, color, transparency, edges, surface (elevation), and shape to obtain the bacterial colony macroscopic characteristics (Logan and Vos 2015).

The results obtained from the bacterial macroscopic observations of ten chitinolytic isolates can be seen in Table 3, while the results obtained from the microscopic observations of bacterial cells can be seen in Table 4 . Colony macroscopic observations were performed in KLA2 and KLA-4 isolates as potential isolates that have the highest chitinolytic index compared to other isolates. Microscopic observations of cells in KLA-2 and KLA-4 isolates had the same cell microscopic characteristics, namely, bacillus cell shape (rod), Gram-positive, and available endospore (Table 4, Figure 2).

According to Sizar et al. Hans Christian Gram created Gram staining method in 1884. Gram-positive bacteria had purplish-blue color after staining with crystal violet-iodine, although being added with bleaching solution of acetone alcohol. Meanwhile, Gram-negative color had red color as the complex dissolved after being added with acetone alcohol and Safranin stain. Color difference indicates that the structural difference in bacterial cell walls (Budin et al. 2012).

\section{Molecular identification of chitinase enzyme-producing bacteria}

From the electrophoresis results of two samples, there were bands that were separated and parallel to the markers of around 1,300 bp (Figure 3). This indicates that the amplified gene fragment was $\pm 1,300 \mathrm{bp}$ in size, which means that the amplification process of two chitinolytic bacterial isolates was successful. The targets achieved were sufficient to identify these bacterial species.

The BLAST analysis results of two chitinolytic isolates in Figure 4 showed that the KLA-2 isolate species was Lysinibacillus fusiformis strain WH22 with a maximum score of 2124, query coverage of $94 \%$, and the identity of 97\%. Meanwhile, KLA-4 isolate species was the Brevibacillus reuszeri strain CMB-15 with a maximum score of 1958 , query coverage of $89 \%$, and identity of $95 \%$ (Figure 5).

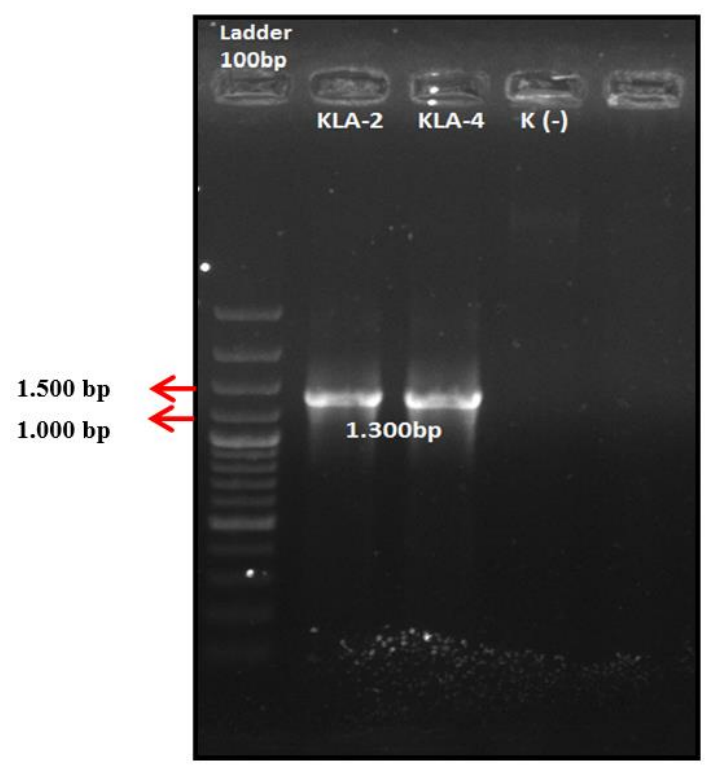

Figure 3. Electrophoresis results from 16S-rRNA gene amplification product

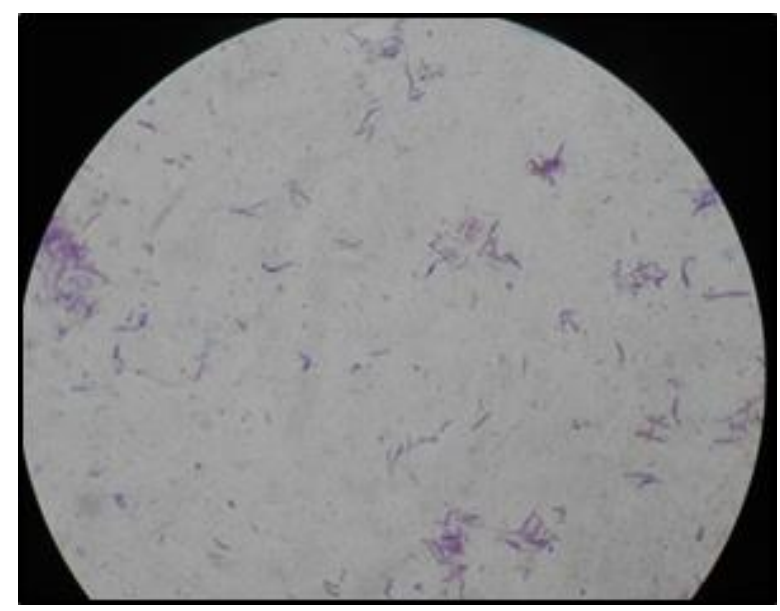

A

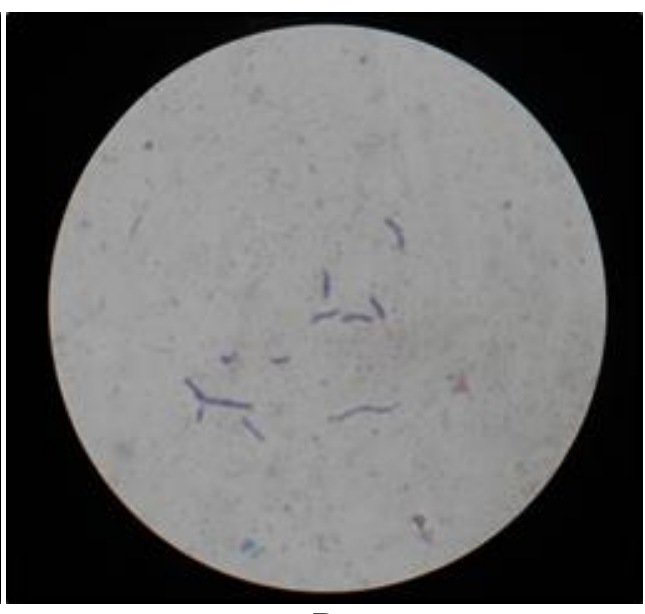

B

Figure 2. Gram staining of two isolates (A. KLA 2, B. KLA 4) with the highest chitinolytic index (microscope magnification 400x) 
Sequences producing significant alignments:

Select: All None Selected:0

\begin{tabular}{|c|c|c|c|c|c|c|c|}
\hline & \multicolumn{7}{|l|}{ Download GenBank Graphics Distance tree of results } \\
\hline & Description & $\begin{array}{l}\text { Max } \\
\text { score }\end{array}$ & $\begin{array}{l}\text { Total } \\
\text { score }\end{array}$ & $\begin{array}{l}\text { Query } \\
\text { cover }\end{array}$ & $\begin{array}{c}E \\
\text { value }\end{array}$ & Ident & Accession \\
\hline$\square$ & Lysinibacillus fusiformis strain WH22 $16 \mathrm{~S}$ ribosomal RNA gene, complete sequence & 2124 & 2124 & $94 \%$ & 0.0 & $97 \%$ & $\underline{F J 418643.1}$ \\
\hline 回 & Lysinibacillus sp. RAB1 $16 \mathrm{~S}$ ribosomal RNA gene, partial sequence & 2122 & 2122 & $94 \%$ & 0.0 & $97 \%$ & $\underline{\text { KR055710.1 }}$ \\
\hline$\square$ & Bacillus sp. B-3-35 16S ribosomal RNA gene, partial sequence & 2122 & 2122 & $94 \%$ & 0.0 & $97 \%$ & $\underline{\mathrm{KT} 583528.1}$ \\
\hline 回 & Bacillus sp. B-3-30 16S ribosomal RNA gene, partial sequence & 2122 & 2122 & $94 \%$ & 0.0 & $97 \%$ & $\underline{\text { KT583523.1 }}$ \\
\hline 回 & Lysinibacillus sp. A-3-10 $16 \mathrm{~S}$ ribosomal RNA gene, partial sequence & 2122 & 2122 & $94 \%$ & 0.0 & $97 \%$ & $\underline{\text { KT583488.1 }}$ \\
\hline$\square$ & Lysinibacillus sp. C-2-31 16S ribosomal RNA gene, partial sequence & 2122 & 2122 & $94 \%$ & 0.0 & $97 \%$ & $\underline{\text { KT583477.1 }}$ \\
\hline 回 & Lysinibacillus sp. C-2-16B $16 \mathrm{~S}$ ribosomal RNA gene, partial sequence & 2122 & 2122 & $94 \%$ & 0.0 & $97 \%$ & $\underline{\mathrm{KT} 583464.1}$ \\
\hline$\square$ & Lysinibacillus sp. B-2-20 $16 \mathrm{~S}$ ribosomal RNA gene, partial sequence & 2122 & 2122 & $94 \%$ & 0.0 & $97 \%$ & $\underline{\text { KT583447.1 }}$ \\
\hline$\square$ & Lysinibacillus sp. C-1-4 16S ribosomal RNA gene, partial sequence & 2122 & 2122 & $94 \%$ & 0.0 & $97 \%$ & $\underline{\text { KT583379.1 }}$ \\
\hline$\square$ & Lysinibacillus sp. C-1-2 $16 \mathrm{~S}$ ribosomal RNA gene, partial sequence & 2122 & 2122 & $94 \%$ & 0.0 & $97 \%$ & $\underline{\mathrm{KT}} 583377.1$ \\
\hline 回 & Lysinibacillus sp. A-1-22 $16 \mathrm{~S}$ ribosomal RNA gene, partial sequence & 2122 & 2122 & $94 \%$ & 0.0 & $97 \%$ & $\underline{\text { KT583328.1 }}$ \\
\hline 回 & Lysinibacillus fusiformis strain M12 $16 \mathrm{~S}$ ribosomal RNA gene, partial sequence & 2122 & 2122 & $94 \%$ & 0.0 & $97 \%$ & KT345669.1 \\
\hline
\end{tabular}

Figure 4. BLAST analysis results for KLA-2 isolate

Sequences producing significant alignments:

Select: All None Selected:0

\begin{tabular}{|c|c|c|c|c|c|c|c|c|}
\hline \multicolumn{2}{|r|}{ Alignments } & \multicolumn{7}{|l|}{ GenBank Graphics Distance tree of results } \\
\hline & & Description & $\begin{array}{l}\text { Max } \\
\text { score }\end{array}$ & $\begin{array}{l}\text { Total } \\
\text { score }\end{array}$ & $\begin{array}{l}\text { Query } \\
\text { cover }\end{array}$ & $\begin{array}{c}E \\
\text { value }\end{array}$ & Ident & Accession \\
\hline 四 & \multicolumn{2}{|c|}{ Brevibacillus reuszeri strain CMB-15 $16 \mathrm{~S}$ ribosomal RNA gene, partial sequence } & 1958 & 1958 & $89 \%$ & 0.0 & $95 \%$ & $\underline{\mathrm{KJ} 186078.1}$ \\
\hline 回 & \multicolumn{2}{|c|}{ Brevibacillus reuszeri strain NA-9 16 S ribosomal RNA gene, partial sequence } & 1947 & 1947 & $89 \%$ & 0.0 & $95 \%$ & $\underline{\text { KU254671.1 }}$ \\
\hline 回 & \multicolumn{2}{|c|}{ Brevibacillus reuszeri strain NA-8 16 S ribosomal RNA gene, partial sequence } & 1947 & 1947 & $89 \%$ & 0.0 & $95 \%$ & $\underline{\text { KU254670.1 }}$ \\
\hline 回 & \multicolumn{2}{|c|}{ Brevibacillus reuszeri partial $16 \mathrm{~S}$ rRNA gene, strain L71 } & 1947 & 1947 & $89 \%$ & 0.0 & $95 \%$ & $\underline{\text { LN8900067.1 }}$ \\
\hline 回 & \multicolumn{2}{|c|}{ Paenibacillus sp. DB14824 16S ribosomal RNA gene, partial sequence } & 1947 & 1947 & $89 \%$ & 0.0 & $95 \%$ & KP670284.1 \\
\hline 回 & \multicolumn{2}{|c|}{ Uncultured bacterium clone PSJGSASTRA 16 S ribosomal RNA gene, partial sequence } & 1947 & 1947 & $89 \%$ & 0.0 & $95 \%$ & $\underline{\mathrm{KR} 013217.1}$ \\
\hline 回 & \multicolumn{3}{|c|}{ Brevibacillus reuszeri strain $\mathrm{BCX}-2216 \mathrm{~S}$ ribosomal RNA gene, partial sequence } & 1947 & $89 \%$ & 0.0 & $95 \%$ & KM378576.1 \\
\hline
\end{tabular}

Figure 5. BLAST analysis results for KLA-4 isolate

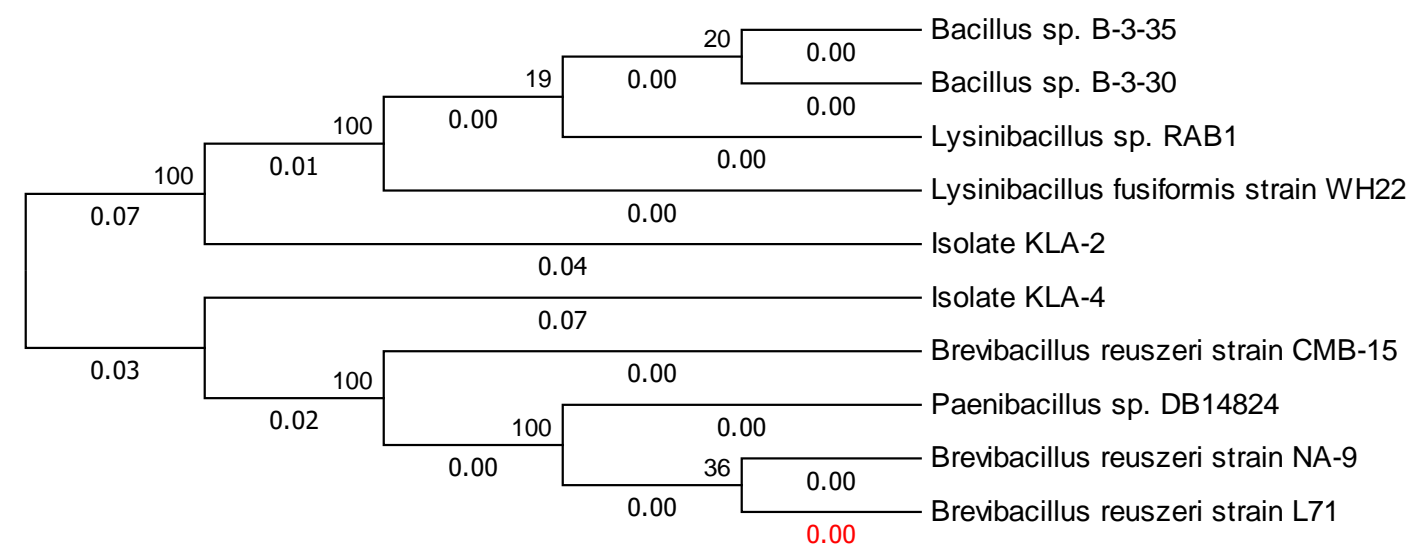

Figure 6. The phylogenetic trees made from both isolates and relative species based on the results of 16S-rRNA analysis 
After KLA-2 and KLA-4 isolates were identified, phylogenetic tree analysis was carried out to precisely construct the relationship between organisms and estimate the differences between one ancestor to the offspring (Amit Roy 2014). 16S-rRNA gene is widely used for phylogenetic tree construction because the nucleotide base sequence among rRNA molecules can be compared precisely (Amit Roy 2014; Woese 1987) and the diversity can be easily identified. Also, 16S-rRNA gene in bacteria has high similarity level presented in all prokaryotes (Tremblay et al. 2015; Woese 1987).

Phylogenetic tree analysis was performed in two stages using the Clustal $W$ program combined with the MEGA 6 (Molecular Evolutionary Genetics Analysis) program to identify the kinship level among species (Horiike 2016). The first stage used the Clustal $W$ program to align the second sequence of chitinolytic bacterial isolates with GenBank sequences, which had similar sequence to KLA-2 and KLA-4 isolates. The MEGA 6 program then created its phylogenetic tree using the "Neighbor Joining" approach with 1000x bootstrap and p-distance method (Horiike 2016; Tamura et al. 2013).

Based on the phylogenetic analysis results in 16S-rRNA in Figure 6, the KLA-2 isolate was closely related to $L$. fusiformis strain WH22 with a genetic distance of 0.04 and a bootstrap value of 100 . The greater the bootstrap value provided, the higher the bootstrap value produced. The reconstructed tree topology could also increase the trustworthiness level (Chang et al. 2019; Reddy et al. 2017). The KLA-4 isolate was closely related to $B$. reuszeri strain CMB-15 with a genetic distance of 0.07 and a bootstrap value of 100 , compared to other types of bacteria in the GenBank.

\section{Lysinibacillus fusiformis}

Lysinibacillus fusiformis was initially known as Bacillus fusiformis before 2007, and then being transferred to Lysinibacillus genus due to different nucleus sequence from Bacillus gene based on the molecular analysis of $16 \mathrm{~S}$ rRNA gene sequence alignments. The meaning of "lysine" in Lysinibacillus genus indicates lysine, alanine, glutamic acid, and aspartic acid in peptidoglycan layer cell wall (Ahmed et al. 2007).

R. K. Singh et al. (2013) successfully isolated chitinolytic bacteria from the rhizosphere of peanut plants in India; after being identified morphologically, biochemically, and molecularly. The chitinolytic bacteria based on 16S-rDNA gene was identified as L. fusiformis $B$ $C M 18$. The chitinase enzyme purification with gel filtration and ion exchange with Sephadex G-100 obtained a molecular weight of $20 \mathrm{kDa}$, a purity of 7.1, a specific chitinase activity of $0.22 \mathrm{U} / \mathrm{mg}$, and an optimum temperature of $35^{\circ} \mathrm{C}$. After finding the purified chitinase enzyme, an in-vitro antifungal activity test of chitinase crude extract against various plant pathogenic fungi. The highest inhibition zones were recorded against Fusarium oxysporum $f$. sp. Ciceri (4.6 mm), Fusarium solani (4.1 $\mathrm{mm})$, Fusarium oxysporumf. sp. lycopersici $(3.8 \mathrm{~mm})$, and Macrophomina phaseolina $(3.4 \mathrm{~mm})$.

This study proves that $L$. fusiformis bacteria can produce chitinase enzyme to degrade chitin and assimilate chitin as carbon and nitrogen sources (Asif et al. 2020). Apart from being chitinolytic bacteria, the L. fusiformis bacteria can also produce protease enzymes (Verma et al. 2016), indole acetic acid, salysil acid, siderophores, which can dissolve phosphate, and can fixate nitrogen (Singh and Kumar 2013). These bacteria can also detoxify factory wastewater ( $\mathrm{He}$ et al. 2011), transform isoeugenol into vanilline (L. Zhao et al. 2016), degrade quorum-sensing molecules of $\mathrm{N}$-acyl-homoserine lactone (Yong et al. 2015), and filter chlorobenzene gas (Z. X. Li et al. 2014), and become a biocontrol agent (Wang et al. 2013).

Rishad et al. (2017) found that Lysinibacillus fusiformis MCB-15 was one of the chitinolytic bacteria from the extraordinary conditions of mangrove environment. Meanwhile, the chitinolytic bacteria source in this study was obtained from shrimp processing factory waste. The bacteria characteristics are greatly influenced by the environment (Cates 2012; More et al. 2014; Persat et al. 2015).

\section{Brevibacillus reuszeri}

Brevibacillus reuszeri was initially known as Bacillus reuszeri before 1996, before being transferred to Brevibacillus genus due to different nucleotide sequence from Bacillus genus based on 16S-rRNA gene sequence molecular analysis alignments (Shida et al. 1996). $B$. reuszeri is a motile Gram-positive bacterium with flagella and ellipsoidal spores. These bacteria have the bacil shape at about $0.5-0.9 \mu \mathrm{m}$ to $2.0-5.0 \mu \mathrm{m}$. The colony formed is flat, smooth, circular, and even. These bacteria are obligate aerobic, which can utilize oxygen to metabolize various sugars and other carbohydrates (Johnson and Dunlap 2019).

Prasanna et al. (2013) succeeded to isolate new strains of bacteria belonging to Brevibacillus genus from mangrove swamp-lands in India, which showed entomopathogenic and chitinolytic activities, namely, $B$. laterosporus.

Several studies have reported the ability of B. reuszeri bacteria, including capable of producing extracellular metalloprotease/thermolysin inhibitors (Kobayashi et al. 2004) to produce L-methionine-N-carbamoylase as potential biocatalyst for L-amino acid production (Nandanwar et al. 2013), phosphate dilution, plant growthpromoting rhizobacteria (PGPR) (Pradesh et al. 2019; Prasad et al. 2019; Yildirim et al. 2011), and antimicrobial bioactive compound production (Gholizadeh et al. 2013; Yang and Yousef 2018).

This study provides new evidence of $B$. reuszeri as chitinolityc bacteria. Although Gurkok (2016) has found $B$. reuszeri as chitinolytic bacteria in marine and terrestrial environments, the $B$. reuszeri identified in this study was obtained from the shrimp processing factory waste with different physical and characterization conditions based on the environmental difference. The nature of bacteria mainly depends on the environmental conditions (Cates 2012; More et al. 2014; Persat et al. 2015).

Ghorbel (2012) successfully isolated chitin from heads, thoraxes, and appendices of shrimp (Metapeneaus 
monoceros). Meanwhile, Benhabiles (2012) successfully isolated chitin from shrimp (Parapenaeus longirostris) shell waste in restaurants. In this study, chitin was also successfully isolated from the shrimp processing factory waste, containing head, tail, and skin. This factory used many kinds of shrimp waste as chitinolytic bacteria sources, which is beneficial to prevent the side effect of waste toward the environment, for sustainable environment.

\section{REFERENCES}

A. Veliz E, Martínez-Hidalgo PM, Hirsch A. 2017. Chitinase-producing bacteria and their role in biocontrol. AIMS Microbiol 3 (3): 689-705. DOI: 10.3934/microbiol.2017.3.689

Ahmed I, Yokota A, Yamazoe A, Fujiwara T. 2007. Proposal of Lysinibacillus boronitolerans gen. nov. sp. nov., and transfer of Bacillus fusiformis to Lysinibacillus fusiformis comb. nov. and Bacillus sphaericus to Lysinibacillus sphaericus comb. nov. Intl J Syst Evol Microbiol 57 (5): 1117-1125. DOI: 10.1099/ijs.0.63867-0.

Amit Roy SR. 2014. Molecular markers in phylogenetic studies-a review. J Phylogenet Evol Biol 2: 2. DOI: 10.4172/2329-9002.1000131.

Asif T, Javed U, Zafar SB, Ansari A, Qader SA, Aman A. 2020 Bioconversion of colloidal chitin using novel chitinase from Glutamicibacter uratoxydans exhibiting anti-fungal potential by hydrolyzing chitin within fungal cell wall. Waste Biomass Valor 11 (8): 4129-4143. DOI: 10.1007/s12649-019-00746-2.

Benhabiles MS, Salah R, Lounici H, Drouiche N, Goosen MFA, Mameri N. 2012. Antibacterial activity of chitin, chitosan and its oligomers prepared from shrimp shell waste. Food Hydrocolloids 29 (1): 48-56. DOI: 10.1016/j.foodhyd.2012.02.013.

Bergey DH, Krieg NR, Holt JG. 1984. Bergey's Manual of Systematic Bacteriology. Williams \& Wilkins, Baltimore, MD.

Berini F, Katz C, Gruzdev N, Casartelli M, Tettamanti G, Marinelli F. 2018. Microbial and viral chitinases: Attractive biopesticides for integrated pest management. Biotechnol Adv 36 (3): 818-838. DOI: 10.1016/j.biotechadv.2018.01.002.

Budin, G, Chung HJ, Lee H, Weissleder R. 2012. A magnetic gram stain for bacterial detection. Angewandte Chemie 124 (31): 7872-7875. DOI: 10.1002/ange.201202982.

Cates, M. E. (2012). Diffusive transport without detailed balance in motile bacteria: Does microbiology need statistical physics? Rep Progr Phys 75 (4): 042601. DOI: 10.1088/0034-4885/75/4/042601.

Chang JM, Floden EW, Herrero J, Gascuel O, Di Tommaso P, Notredame C. 2019. Incorporating alignment uncertainty into Felsenstein's phylogenetic bootstrap to improve its reliability. Bioinformatics 2019. (Feb): 6. DOI: 10.1093/bioinformatics/btz082.

Chernin LS, Winson MK, Thompson JM, Haran S, Bycroft BW, Chet I, Williams P, Stewart, GSAB. 1998. Chitinolytic activity in Chromobacterium violaceum: Substrate analysis and regulation by quorum sensing. J Bacteriol 180 (17): 4435-4441. DOI: 10.1128/jb.180.17.4435-4441.1998.

Das S, Roy D, Sen R. 2016. Utilization of chitinaceous wastes for the production of chitinase. In: Advances in Food and Nutrition Research. 1st ed., Vol. 78. Elsevier Inc., New York. DOI: 10.1016/bs.afnr.2016.04.001.

Dliyauddin MOH, Ardyati TRI, Suharjono. 2020. Evaluation of enzymatic activity and identification of potent proteolytic and chitinolytic bacteria isolated from crab shell waste. Biodiversitas 21 (1): 211-218. DOI: $10.13057 /$ biodiv/d210127.

Drewnowska JM, Fiodor A, Barboza-Corona JE, Swiecicka I. 2020. Chitinolytic activity of phylogenetically diverse Bacillus cereus sensu lato from natural environments. Syst Appl Microbiol 43 (3): 126075 DOI: 10.1016/j.syapm.2020.126075.

Elieh-Ali-Komi D, Hamblin MR. 2016. Chitin and chitosan: production and application of versatile biomedical nanomaterials. Intl J Adv Res 4 (3): 411-427.

Gholizadeh SS, Baserisalehi M, Bahador N. 2013. Study on bioactive compounds produced by soil origin Brevibacillus spp. Nature Environ Pollut Technol 12 (2): 209-214.
Ghorbel-Bellaaj O, Younes I, Maâlej H, Hajji S, Nasri M. 2012. Chitin extraction from shrimp shell waste using Bacillus bacteria. Intl J Biol Macromol 51 (5): 1196-1201. DOI: 10.1016/j.ijbiomac.2012.08.034.

Gohel V, Chaudhary T, Vyas P, Chhatpar HS. 2006. Statistical screenings of medium components for the production of chitinase by the marine isolate Pantoea dispersa. Biochem Eng J 28 (1): 50-56. DOI: 10.1016/j.bej.2005.09.002.

Gupta MM, Chourasiya D, Sharma MP. 2019. Diversity of arbuscular mycorrhizal fungi in relation to sustainable plant production systems. In: Satyanarayana T, Das S, Johri B. (eds.). Microbial Diversity in Ecosystem Sustainability and Biotechnological Applications. Springer, Singapore. DOI: 10.1007/978-981-13-8487-5_7.

Gürkök S, Görmez A. 2016. Isolation and characterization of novel chitinolytic bacteria. AIP Conf Proc 1726: 020017. DOI: 10.1063/1.4945843.

Halder SK, Maity C, Jana A, Das A. Paul T, Das Mohapatra PK, Pati BR, Mondal KC. 2013. Proficient biodegradation of shrimp shell waste by Aeromonas hydrophila SBK1 for the concomitant production of antifungal chitinase and antioxidant chitosaccharides. Intl Biodeterior Biodegrad 79: 88-97. DOI: 10.1016/j.ibiod.2013.01.011.

Haliza W. 2016. Karakteristik kitinase dari mikrobia. Buletin Teknologi Pasca Panen 8 (1): 1-14. [Indonesian]

He M, Li X, Liu H, Miller SJ, Wang G, Rensing C. 2011. Characterization and genomic analysis of a highly chromate resistant and reducing bacterial strain Lysinibacillus fusiformis ZC1. J Hazard Mater 185 (23): 682-688. DOI: 10.1016/j.jhazmat.2010.09.072.

Horiike T. 2016. An introduction to molecular phylogenetic analysis. Rev Agric Sci 4 (0): 36-45. DOI: 10.7831/ras.4.36.

Hsu SC, Lockwood JL. 1975. Powdered chitin agar as a selective medium for enumeration of actinomycetes in water and soil. Appl Microbiol 29 (3): 422-426. DOI: 10.1128/am.29.3.422-426.1975.

Jeyanthi Rebecca L, Susithra G, Sharmila S, Das MP. 2013. Isolation and screening of chitinase-producing Serratia marcescens from soil. J Chem Pharmaceut Res 5 (2): 192-195.

Johnson ET, Dunlap CA. 2019. Phylogenomic analysis of the Brevibacillus brevis clade: a proposal for three new Brevibacillus species, Brevibacillus fortis sp. nov., Brevibacillus porteri sp. nov. and Brevibacillus schisleri sp. nov. Antonie van Leeuwenhoek Intl J Gen Mol Microbiol 112 (7): 991-999. DOI: 10.1007/s10482-01901232-4.

Junianto J, Wahyuntari B, Setyahadi S. 2013. Selection of methods for microbiological extraction of chitin from shrimp shells. Microbiol Indonesia 7 (2): 75-83. DOI: 10.5454/mi.7.2.5.

Kaur K, Dattajirao V, Shrivastava V, Bhardwaj U. 2012. Isolation and characterization of chitosan-producing bacteria from beaches of Chennai, India. Enzyme Res. DOI: 10.1155/2012/421683.

Kim YH, Park SK, Hur JY, Kim YC. 2017. Purification and characterization of a major extracellular chitinase from a biocontrol bacterium, Paenibacillus elgii HOA73. Plant Pathol J 33 (3): 318328. DOI: 10.5423/PPJ.FT.01.2017.0022

Kobayashi T, Nakagawa N, Imada C, Hamada-Sato N, Watanabe E. 2004. Occurrence of a metalloprotease (thermolysin) inhibitor among Brevibacillus species and purification of such inhibitor from Brevibacillus reuszeri IFO 15719T. Fisheries Science 70 (2): 299305. DOI: 10.1111/j.1444-2906.2003.00804.x

Lay B. 1994. Analisis Mikroba di Laboratorium (1st ed.). PT Raja Grafindo Persada. [Indonesian]

Le B, Yang SH. 2019. Microbial chitinases: properties, current state and biotechnological applications. World J Microbiol Biotechnol 35 (9): 144. DOI: 10.1007/s11274-019-2721-y.

Li S, Pearl DK, Doss H. 2000. Phylogenetic tree construction using Markov Chain Monte Carlo. J Am Stat Assoc 95 (450): 493-508. DOI: 10.1080/01621459.2000.10474227.

Li Y, Lei X, Zhu H, Zhang H, Guan C, Chen Z, Zheng W, Fu L, Zheng T. 2016. Chitinase-producing bacteria with direct algicidal activity on marine diatoms. Sci Rep 6: 57-65. DOI: 10.1038/srep21984.

Li ZX, Yang BR, Jin JX, Pu YC, Ding C. 2014. The operating performance of a biotrickling filter with Lysinibacillus fusiformis for the removal of high-loading gaseous chlorobenzene. Biotechnol Lett 36 (10): 1971-1979. DOI: 10.1007/s10529-014-1559-5.

Logan NA, Vos P De. 2015. Bacillus. In Bergey's Manual of Systematics of Archaea and Bacteria. DOI: 10.1002/9781118960608.gbm00530

Monge EC, Tuveng TR, Vaaje-Kolstad G, Eijsink VGH, Gardner JG. 2018. Systems analysis of the glycoside hydrolase family 18 enzymes from Cellvibrio japonicus characterizes essential chitin degradation 
functions. J Biol Chem 293 (10): 3849-3859. DOI: 10.1074/jbc.RA117.000849.

More TT, Yadav JSS, Yan S, Tyagi RD, Surampalli RY. 2014 Extracellular polymeric substances of bacteria and their potentia environmental applications. J Environ Manag 144: 1-25. DOI: 10.1016/j.jenvman.2014.05.010

Najafi MF, Deobagkar D, Deobagkar D. 2005. Purification and characterization of an extracellular $\alpha$-amylase from Bacillus subtilis AX20. Protein Expression Purif 41 (2): 349-354. DOI: 10.1016/j.pep.2005.02.015.

Nandanwar HS, Vohra RM, Hoondal GS. 2013. Trimeric 1-Ncarbamoylase from newly isolated Brevibacillus reuszeri HSN1: A potential biocatalyst for production of $1-\alpha$-amino acids. Biotechnol Appl Biochem 60 (2): 219-230. DOI: 10.1002/bab.1066.

Noreen N, Ramzan N, Perveen Z, Shahzad S, Noreen N, Al ET. 2018. Assessing the enzymatic activities of compost-associated mesophilic. Thermotolerant Thermophilic Bacteria Fungi 15: 815-825.

Osamu S, Takagi H, Kadowaki KKK. 1996. Proposal for two new genera, Brevibacillus gen. nov. and Aneurinibacillus gen. nov. Intl J Syst Bacteriol 46 (4): 939-946.

Parnell JJ, Berka R, Young HA, Sturino JM, Kang Y, Barnhart DM, Dileo MV. 2016. From the lab to the farm: An industrial perspective of plant beneficial microorganisms. Front Plant Sci 7: 1110. DOI: $10.3389 /$ fpls.2016.01110

Patil RS, Ghormade V, Deshpande MV. 2000. Chitinolytic enzymes: An exploration. Enzyme Microb Technol 26 (7): 473-483. DOI: 10.1016/S0141-0229(00)00134-4.

Persat A, Nadell CD, Kim MK, Ingremeau F, Siryaporn A, Drescher K, Wingreen NS, Bassler BL, Gitai Z, Stone HA. 2015. The mechanical $\begin{array}{lllll}\text { world of bacteria. Cell } 161 & \text { (5): 988-997. DOI }\end{array}$ 10.1016/j.cell.2015.05.005

Pradesh H, Yadav N, Pradesh U, Kumar A, South RG, Pradesh U, Meena VS, Division CP. 2019. Plant growth-promoting rhizobacteria for agricultural sustainability. In: Kumar A, Singh Meena V (eds.).Plant Growth Promoting Rhizobacteria for Agricultural Sustainability: From Theory to Practices. Springer, Berlin. DOI: 10.1007/978-98113-7553-8.

Prasad M, Srinivasan R, Chaudhary M, Choudhary M, Jat LK. 2019. Plant Growth Promoting Rhizobacteria (PGPR) for sustainable agriculture. In: PGPR Amelioration in Sustainable Agriculture. Elsevier Inc., New York. DOI: 10.1016/b978-0-12-815879-1.00007-0.

Prasanna L, Eijsink VGH, Meadow R, Gåseidnes S. 2013. A novel strain of Brevibacillus laterosporus produces chitinases that contribute to its biocontrol potential. Appl Microbiol Biotechnol 97 (4): 1601-1611. DOI: $10.1007 / \mathrm{s} 00253-012-4019-\mathrm{y}$.

Reddy S, Kimball RT, Pandey A, Hosner PA, Braun MJ, Hackett SJ, Han KL, Harshman J, Huddleston CJ, Kingston S, Marks BD, Miglia KJ, Moore WS, Sheldon FH, Witt CC, Yuri T, Braun EL. 2017. Why do phylogenomic data sets yield conflicting trees? Data type influences the avian tree of life more than taxon sampling. Syst Biol 66 (5): 857 879. DOI: $10.1093 /$ sysbio/syx041.

Rishad KS, Rebello S, Shabanamol PS, Jisha MS. 2017. Biocontrol potential of halotolerant bacterial chitinase from high yielding novel Bacillus pumilus MCB-7 autochthonous to mangrove ecosystem. Pesticide Biochem Physiol 137: 36-41. DOI 10.1016/j.pestbp.2016.09.005.

Saima, Kuddus M, Roohi, Ahmad IZ. 2013. Isolation of novel chitinolytic bacteria and production optimization of extracellular chitinase. Genet Eng Biotechnol 11 (1): 39-46. DOI 10.1016/j.jgeb.2013.03.001.

Shahidi F, Arachchi JKV, Jeon YJ. 1999. Food applications of chitin and chitosan. Trends Food Sci Technol 10 (2): 37-51. DOI: 10.1016/S0924-2244(99)00017-5.

Shamshina JL. 2019. Chitin in ionic liquids: Historical insights into the polymer's dissolution and isolation. A review. Green Chem 21 (15): 3974-3993. DOI: $10.1039 / \mathrm{c} 9 \mathrm{gc} 01830 \mathrm{a}$.

Singh R, Upadhyay SK, Singh M, Sharma I, Sharma P, Kamboj P, Saini A, Voraha R, Sharma AK, Upadhyay TK, Khan F. 2020. Chitin, chitinases and chitin derivatives in biopharmaceutical, agricultural and environmental perspective. Biointerface Res Appl Chem 11 (3): 9985-10005. DOI: 10.33263/BRIAC113.998510005.

Singh RJ, Kumar DP, Singh P. 2013. Multifarious plant growth-promoting characteristics of chickpea rhizosphere-associated Bacilli help to suppress soil-borne pathogens. Plant Growth Regulation, Springer 73 (1): 91-101.
Singh RK, Kumar DP, Solanki MK, Singh P, Srivastva AK, Kumar S, Kashyap PL, Saxena AK, Singhal PK, Arora DK. 2013. Optimization of media components for chitinase production by chickpea rhizosphere associated Lysinibacillus fusiformis B-CM18. J Basic Microbiol 53 (5): 451-460. DOI: 10.1002/jobm.201100590.

Soeka YS, Sulistiani S. 2012. Seleksi, karakterisasi, dan identifikasi bakteri penghasil kitinase yang diisolasi dari Gunung Bromo, Jawa Timur. Jurnal Natur Indonesia 13 (2): $155 . \quad$ DOI: 10.31258/jnat.13.2.155-161. [Indonesian]

Suryadi Y, Priyatno TP, Samudra IM, Susilowati DN, Lawati N, Kustaman E. 2016. Pemurnian parsial dan karakterisasi kitinase asal jamur entomopatogen Beauveria bassiana isolat BB200109. Jurnal AgroBiogen 9 (2): 77. DOI: 10.21082/jbio.v9n2.2013.p77-84.

Taira T, Ohnuma T, Yamagami T, Aso Y, Ishiguro M, Ishihara M. 2002. Antifungal activity of rye (secale cereale) seed chitinases: The different binding manner of class $i$ and class ii chitinases to the fungal cell walls. Biosci Biotechnol Biochem 66 (5): 970-977. DOI: 10.1271/bbb.66.970.

Tamura K, Stecher G, Peterson D, Filipski A, Kumar S. 2013. MEGA6: Molecular evolutionary genetics analysis version 6.0. Mol Biol Evol 30 (12): 2725-2729. DOI: $10.1093 / \mathrm{molbev} / \mathrm{mst} 197$.

Terayama H, Kuzuhara H. 1993. Large-scale preparation of $n, n,-$ diacetylchitobiose by enzymic degradation of chitin and its chemical modifications. J Carbohydr Chem 12 (1): 81-93. DOI: $10.1080 / 07328309308018542$

Tran TN, Doan CT, Nguyen VB, Nguyen AD, Wang SL. 2019. The isolation of chitinase from Streptomyces thermocarboxydus and its application in the preparation of chitin oligomers. Res Chem Intermed 45 (2): 727-742. DOI: 10.1007/s11164-018-3639-y.

Tremblay J, Singh K, Fern A, Kirton ES, He S, Woyke T, Lee J, Chen F, Dangl JL, Tringe SG. 2015. Primer and platform effects on 16S rRNA tag sequencing. Front Microbiol 6: 771. DOI: 10.3389/fmicb.2015.00771.

Verma P, Yadav AN, Khannam KS, Kumar S, Saxena AK, Suman A. 2016. Molecular diversity and multifarious plant growth promoting attributes of Bacilli associated with wheat (Triticum aestivum L.) rhizosphere from six diverse agro-ecological zones of India. J Basic Microbiol 56 (1): 44-58. DOI: 10.1002/jobm.201500459.

Wang K, Yan P sheng, Ding Q, long WQ, xi Wang Z, bo Peng J. 2013. Diversity of culturable root-associated/endophytic bacteria and their chitinolytic and aflatoxin inhibition activity of peanut plant in China. World J Microbiol Biotechnol 29 (1): 1-10. DOI: 10.1007/s11274012-1135-x.

Widhyastuti N. 2007. Produksi kitinase ekstraseluler Aspergilus rugulosus 501 secara optimal pada media cair. Berita Biologi 8 (6): 547-553. [Indonesian]

Woese CR. 1987. Bacterial evolution. Microbiol Rev 51 (2): 221-271. DOI: $10.1128 / \mathrm{mmbr} .51 .2 .221-271.1987$

Yan Q, Fong SS. 2015. Bacterial chitinase: Nature and perspectives for sustainable bioproduction. Bioresour Bioprocess 31: 2015. DOI: 10.1186/s40643-015-0057-5.

Yang X, Yousef AE. 2018. Antimicrobial peptides produced by Brevibacillus spp.: structure, classification and bioactivity: a minireview. World J Microbiol Biotechnol 34 (4): 57. DOI: 10.1007/s11274-018-2437-4.

Yavari-Bafghi M, Babavalian H, Amoozegar MA. 2019. Isolation, screening and identification of haloarchaea with chitinolytic activity from hypersaline lakes of Iran. Arch Biol Sci 71 (1): 71-81. DOI: 10.2298/ABS180525049Y.

Yildirim E, Karlidag H, Turan M, Dursun A, Goktepe F. 2011. Promotion of broccoli by plant growth-promoting rhizobacteria. Hort Sci 46 (6): 932-936.

Yong D, Ee R, Lim YL, Chang CY, Yin WF, Chan KG. 2015. Insights on quorum-quenching properties of Lysinibacillus fusiformis strain RB21, a Malaysian municipal solid-waste landfill soil isolate, via complete genome sequence analysis. Genome Announcements 3 (3): 2014-2015. DOI: 10.1128/genomeA.00409-15.

Yurnaliza Y, Margino S, Sembiring L. 2012. Kemampuan kitinase Streptomyces RKt5 sebagai Antijamur terhadap patogen Fusarium oxysporum. Jurnal Natur Indonesia 14 (1): $42 . \quad$ DOI: 10.31258/jnat.14.1.42-46.

Zhao L, Bao G, Geng B, Song J, Li Y. 2016. Draft genome sequence of Lysinibacillus fusiformis strain SW-B9, a novel strain for biotransformation of isoeugenol to vanillin. Genome Announcements 3 (2): 9-10. DOI: 10.1128/genomeA.00289-15. 
Zhao Z, Baltar F, Herndl GJ. 2020. Linking extracellular enzymes to phylogeny indicates a predominantly particle-associated lifestyle of deep-sea prokaryotes. Sci Adv 6 (16): 1-11. DOI: 10.1126/sciadv.aaz4354. 